\title{
Construction of Environmental Science Professional, and Improvement of Undergraduate Talent Quality
}

\author{
Zheng-Hao Fei , Jing-Ping Wang, Xin-Hong Wang, Jian Chen, Zong-Tang Liu \\ School of Chemical and Environmental Engineering, Yancheng Teachers University, \\ Jiangsu, 224002, China,
}

The research is supported by a Project Funded by the brand professional project form Yancheng teachers college (2016) and the teaching reform and practice of medicinal chemistry (2018YCTUJGY006) and the Flagship Major Development of Jiangsu Higher Education Institutions"'(PPZY2015B113)。

\section{Abstract}

Teaching quality is the lifeline of higher education, and advantages and characteristics are important conditions for the survival and development of higher education. It is the practical way to deepen the reform of talent cultivation mode and improve the overall quality of running a school. Based on the connotation of brand specialty, this paper puts forward the measures and methods of building brand specialty from the aspects of teaching staff construction, curriculum construction, teaching material construction, practical teaching and teaching management, and probes into the practice and thinking of building environmental science brand specialty and characteristic specialty.

Keywords Brand major; Teaching quality; Advantages and characteristics; Construction measures

DOI: $10.7176 / \mathrm{JEP} / 10-33-16$

Publication date: November $30^{\text {th }} 2019$

\section{Introduction}

College brand specialty construction is another key reform measure in college field. The state encourages colleges and universities to concentrate superior resources, build brand majors as the goal, innovate the talent cultivation mode of colleges and universities, and build the top talent cultivation base. We should guide college brand majors to give full play to the advantages of their own characteristics, highlight practical teaching, improve their contribution to social and economic development, enhance their core competitiveness, and promote the construction of brand disciplines. ${ }^{[1-3]}$ Focusing on the reform of personnel training mode, teaching content, curriculum system, teaching methods and means, we should strengthen the awareness of brand, characteristic, competition and innovation. We should pay attention to the scientific, systematic, comprehensive and continuous reform, promote the basic construction of all kinds of teaching with the construction of brand specialty, promote the deepening of teaching reform, and improve the overall level of the whole school. ${ }^{[4]}$ Brand specialty has higher requirements on the development of disciplines, teaching level and scientific research strength. Brand majors should constantly optimize the structure of professional teachers, improve the overall level of teaching and scientific research. We combine our own reality, from the connotation of brand specialty, from the construction of teaching staff, curriculum, teaching materials, practical teaching and teaching management and other aspects of brand specialty construction measures and methods, to explore the construction of environmental science brand specialty, characteristic specialty practice road.

\section{Combination of the introduction and cultivation of teaching staff}

The research level of high, optimized structure, a good scientific research or professional technical background is full of vitality of the professional faculty. Through the optimization of the teacher team, according to the requirements of professional talent training objectives, under the guidance of professional construction objectives, give full play to the subjective initiative of teachers, form a benign situation of excellent teaching quality, high scientific research level and good social services, and provide support for the final construction of a good brand professional.

The construction of teaching staff is the core of brand specialty construction ${ }^{[5]}$. To strengthen the construction of the teaching staff, we must take various effective measures to stabilize and strengthen the teaching staff, improve the educational level of the teaching staff, improve the knowledge structure and enhance the professional quality through the combination of introduction and training and the establishment of institutional constraints. (1) Introduction. First, we will introduce high-level academic backbones, especially academic leaders who have made outstanding achievements in scientific research. Second, the introduction of professional and technical personnel, especially from enterprises and institutions to introduce both practical work experience, and a solid theoretical foundation of professional staff to enrich the teacher team, increase the 
proportion of "double quality" teachers. Through the input of new blood, improve the structure of teachers, form a echelon of teachers, enhance the vitality of the team. (2) Cultivation. First, to train professional leaders and key teachers to improve their academic level and research ability; The second is to train young teachers, improve the level of teaching and academic qualifications; Third, training double-qualified teachers, encouraging and supporting teachers to practice, directly participating in production process and teaching guidance, cooperating with enterprises in project development, and strengthening teachers' practical ability. (3) Employment. Hire parttime teachers and visiting professors from the front line of work, hire high-level foreign teachers, and establish an appropriate and relatively stable number of part-time teachers, so that students can timely understand the forefront of knowledge and technology, and constantly broaden their horizons.

The major of environmental science focuses on training teachers for specialized courses and core courses, and currently introduces high-level double-qualified talents of environmental science with strong production practice $^{[6]}$. To introduce PHDS in environmental science with overseas study experience and PHDS in environmental science and environmental engineering; Strengthen in-service teacher training and training, support teachers to go to the United States as visiting scholars to study scientific research; To strengthen horizontal cooperation, we have cooperated with yancheng environmental protection technology and engineering research institute of nanjing university for many times to run a school, and carried out professional training for environmental protection practitioners in the position of analysis and testing, so as to go deep into the front line of production and improve the professional level of engineering.

There are 16 students in this major, among whom 12 teachers have doctor's degree, accounting for $75 \%$. With a master's degree of more than 94 percent, 13 senior titles, the proportion of more than 81 percent, double quality teacher 1, accounting for 6 percent. At present, we have 12 experts and professors who have a certain influence in the fields of chemistry and environmental science. Teachers of this major love their job and are dedicated to their work. They have a rigorous attitude towards academic research and a strong enterprising spirit. They are willing to make contributions and have won many honors. Environmental science has initially formed an obvious echelon, high ideological quality, professional quality, development potential, a reasonable structure of teachers.

\section{Research and reform of education and teaching}

Adapt to the development of the discipline, constantly adjust and improve the curriculum system of brand specialty, actively carry out the construction of major key courses, optimize the combination of teaching content, clear the relationship between courses, do a good job in the connection between courses, save teaching hours, improve the efficiency of running a school. Through the construction of course group of "face", exquisite course construction as the "point", in the course system and teaching content update the exquisite course construction on the basis of the optimization ${ }^{[7]}$. Pay attention to experimental teaching content and method, experimental examination method reform, through the selection of experimental content, to leave students with the development of personality, expand the space of thinking; Through basic experiments, cultivate students' spirit and methods of scientific experiments, and train strict and rigorous work style; Through the development of comprehensive and in the course system design formed a "three platforms compulsory, four types of elective" flexible course system, the new course system can not only build a wide range of talent knowledge structure and quality structure, but also effectively strengthen the professional skills training, reflects the strengthening of the foundation, broaden the professional, strengthen practice, improve the quality of teaching principles, change the course content obsolete, too detailed and simple to put together the situation, avoid the curriculum repetition and focus on innovative experimental teaching links. Through the construction of high-quality courses, to promote the construction and introduction of high-level teaching materials; Introduce multimedia, network teaching and other advanced educational technology, to achieve the modernization of teaching and experimental means, teaching content information, improve the quality of teaching and modern teaching level; Hire professors on the platform, strengthen the professional basic courses and main courses teaching force, to ensure the quality of student training; In accordance with the requirements of cultivating high-quality talents in the new century, we should continuously deepen the teaching reform, optimize the curriculum system, strengthen the construction of teaching materials, update the teaching content, actively organize multimedia teaching and bilingual teaching, earnestly strengthen the practical teaching links, and cultivate and produce a number of outstanding teaching reform and scientific research results. From January 2016 to September 2019, I won one jiangsu provincial education teaching and research achievement award (third prize) in 2018 organized by the education department of jiangsu province, completed two school-level teaching reform projects and applied for three projects. I have applied for "university-level quality open online course cultivation and construction project", and published 31 teaching research papers in total. In the teaching skills competition of teachers, I have participated in the teaching competition of teachers in colleges and universities for many times and won the second prize. The construction of teaching staff has been fruitful and fruitful. 


\section{Remarkable achievements in the construction of curriculum and textbook resources}

With the principle of selecting and compiling excellent textbooks, teachers are encouraged, supported and organized to compile high-quality professional textbooks. Through the construction of teaching materials, on the one hand, timely update and enrich the teaching content, so that students know the latest results of the subject development; On the other hand, to promote teachers to in-depth and systematic study of teaching content, so as to further improve the teaching level. To effectively raise the quality of courses and around online, offline and online mixing, virtual simulation and social practice this Angle to build five classroom teaching as the main position and teachers "teaching" as the center to the students "learning" as the center, to explore the wisdom innovative thinking and innovative application of the new mode of teaching development, applied for a 1 "instrument analysis" SPOC course projects, the environmental impact assessment field quality online open courses to foster 1 construction projects, power environmental science professional improve the teaching quality; Six textbooks have been published, among which physical chemistry and instrumental analysis experiment and inorganic and analytical chemistry are the key textbooks in jiangsu province. This major has excellent core courses "environmental monitoring and experiment", "environmental chemistry", "instrumental analysis" and established the corresponding test paper library; Has established the "organic chemistry ( I )" and "environmental testing experiment" bilingual courses so as to adapt to China's accession to the WTO gradually integrated into the international requirements.

\section{Ppractical teaching and practical ability}

Curriculum implementation of the "6 + 1" module structure, the system of "6" is composed of basic experiment and innovative experiment, professional practice, (research) of science and technology activities, social practice and graduation thesis six relatively independent, each have emphasize particularly on and complement each other, mutually supporting module as the foundation, to ensure and strengthen the normal operation of the open experiment "1", to ensure the effect of open experiment. Set up practical training base to strengthen students' engineering practice ability. We and yancheng city environmental monitoring center, jianhu county, yancheng city, east of the city sewage treatment plant, solid waste disposal center co., LTD., dongtai environmental monitoring station, yancheng, yancheng city, south of the city sewage treatment plant, the food and drug inspection, and a number of enterprises set up in yancheng Long Gang salt lake training relations of cooperation, as environmental science professional off-campus practice bases, and expand the teaching space, make the teachers and students mastering environment science and technology, improve the students entered the social adaptation ability.

Increase laboratory opening. Attract interested students to enter the laboratory to carry out scientific and technological activities in and out of class and participate in the scientific research work of teachers of this major. In the scientific research activities, students' theoretical knowledge level, hands-on ability, observation, analysis and problem solving ability have been improved. At the same time, their team spirit and awareness of mutual help and friendship have been enhanced.

It strengthens the link of practice teaching and constructs a new system of practice teaching. Students in the research room through the participation in team training, obtained gratifying results, many times won the outstanding graduation thesis award. Positive, according to the college students' innovative entrepreneurial training program in related disciplines, for strong support, and related industries, business or profession to establish close contact, increase the construction funds investment, strong professional teaching infrastructure construction, improve professional educational condition, the condition of experiment, practice, practice can meet face-to-face teaching requirements, to ensure the sustainable development of specialty construction. Added in order to ensure the coordinated development of environment and economy, yancheng and yancheng environmental technology and engineering institute of nanjing university union school, carry out environmental protection practitioners systematic and normal type, professional education and training, and implementation to strengthen environmental protection consciousness and the personnel quality of the connotation of "strengthening foundation up project", hold many coastal chemical industry park enterprise wastewater treatment plants (station, workshop) personnel training, to coastal and lianyungang chemical industrial park of environmental governance for thrift, from the enterprise, head of research, industrial wastewater treatment technology, analysis, testing job skills and exhaust management backbone four aspects to carry out the training, The purpose is to enhance the environmental protection awareness of the enterprise leaders in the park and control the development level, enhance the professional skills of the industry backbone, promote the healthy development of the park, and cultivate applied talents for the environmental protection industry. 


\section{Students' innovative consciousness and their practical ability}

It is an important way to make full use of social resources and cultivate senior specialized talents, as well as an important measure to build brand specialty. To achieve school-enterprise cooperation, enterprises can play five important roles in brand specialty construction :(1) participate in the formulation and implementation of talent training programs, timely feedback the industry development needs for professional talents to the teaching link, so that each link in the teaching plan not only conforms to the teaching rules, but also meets the industry needs; (2) provide stable off-campus internship and training base to train students' technical application ability to comprehensively apply theoretical knowledge to solve practical problems, fully explore students' creative potential, enhance their innovative spirit, and further improve the effect of talent training; (3) provide advanced equipment, technology and technology, so that students can learn and master advanced professional technical knowledge and skills in a timely manner, and lead the development of the industry with advanced technology; (4) provide front-line high-level production talents to participate in teaching work, cultivate double-qualified talents, and strengthen the teaching team; (5) provide jobs for graduates.

By establishing an effective mechanism of school-enterprise cooperation, the brand specialty provides technology and services for the industry and enterprises, and the industry and enterprises participate in the whole process of the professional teaching reform, so that the professional construction is more contemporary and forward-looking, and truly realize the mutual benefit and win-win between the school and enterprise. Encourage environmental science students to actively participate in innovation and entrepreneurship training and competition, and win various awards. For example, in 2016, the 4th "challenge cup" college student entrepreneurship plan competition of "chuangchuang youth" of avic national college student entrepreneurship competition won one national gold award; Students of ordinary colleges and universities in jiangsu province won 2 special prizes, 2 first prizes and 2 second prizes in the invitational contest of water treatment experiment. Students majoring in environmental science from grade 14 to grade 16 participated in the second "general analysis cup" environmental monitoring skills competition of yancheng university and won 3 special prizes, 6 first prizes and several second prizes respectively. Participated in the fifth "oberl" cup chemistry and chemical engineering experiment competition for college students in jiangsu province, and won 2 first prizes; 1 second prize; Third prize 1 item; 2 prizes for winning; Participated in the 7 th college students chemical engineering design competition in jiangsu province and won 1 second prize; Participated in the second China "Internet + " college students' innovation and entrepreneurship competition "CCB cup" held by the education department of jiangsu province, and won one third prize at the provincial level.

\section{Strengthen international exchanges and cooperation and improve professional quality}

Environmental science teachers were selected to go to John Crittenden university in the United States for overseas study of environmental engineering. In the summer of 2018, 15 students were led to Australia for 20 days of overseas study.

\section{Conclusion}

It takes a long time to build a brand specialty, which requires continuous all-round organizational operation and long-term persistence, and also requires a certain amount of capital investment. At the same time, we should establish a set of scientific brand professional evaluation system, in order to achieve the brand professional evaluation, feedback and prediction, fully guide the professional brand operation. Keep pace with The Times, constantly strengthen the construction of environmental science professional brand, improve the quality of environmental science professional.

\section{References}

[1] Jing Liu, Qi Zhang, Si-zhuo Chen. An empirical study on talent training based on the data of some universities in jilin province [J]. Human resource management, 2017, 31 (8) : 213-215.

[2] Qian Feng. Current situation analysis and strategy research on informatization construction of university brand specialty in jiangsu province [J]. Journal of yangzhou university (higher education research edition), 2007,10 (3) : 12-14.

[3] Xin-mei Sha. Three basic problems in the construction of disciplines and majors in application-oriented universities [J]. Chinese university teaching, 2016, 37 (12) : 47-51.

[4] Bing-lin Zhong, Zhi-he Li. An analysis of discipline construction and specialty construction in undergraduate universities [J]. China higher education, 2015, 50 (22) : 19-23. 
[5] Hong-xin Jiang. Strengthening education orientation and promoting first-class discipline construction [J]. Chinese university teaching, 2016, 37 (11) : 44-46, 92.

[6] Lan Huang, Yan-long Jiang, Qii-qian Kong. Quality characteristics of top talents in science and technology and ecological optimization of university education [J]. Higher education research, 2017, 38 (1) : 55-61.

[7] Yan-bao Li. Thinking on the orientation of talent training objectives in the construction of "double first-class" universities [J]. Science and technology of Chinese universities, 2017, 30 (1) : 4-6. 